\title{
Ecological and hydrological considerations for climber weed control in freshwater forested wetland restoration project on the Gulf of Mexico
}

\section{Laura Aguirre Franco}

Universidad Nacional Autónoma de México: Universidad Nacional Autonoma de Mexico

Patricia Moreno-Casasola ( $\square$ patricia.moreno@inecol.mx )

INECOL: Instituto de Ecologia https://orcid.org/0000-0003-0468-0851

Roberto Lindig Cisneros

Universidad Nacional Autónoma de México: Universidad Nacional Autonoma de Mexico

Diego Pérez-Salicrup

Universidad Nacional Autónoma de México: Universidad Nacional Autonoma de Mexico

\section{Research Article}

Keywords: Ipomoea tiliacea, Ipomoea indica, light conditions, trellis availability, wetland management

Posted Date: April 20th, 2021

DOI: https://doi.org/10.21203/rs.3.rs-392954/v1

License: (9) This work is licensed under a Creative Commons Attribution 4.0 International License. Read Full License 


\section{Abstract}

Two herbaceous Ipomoea climbers grow over trees planted to restore a freshwater forested wetland in the Gulf of Mexico, causing high tree mortality and limiting restoration success. To better control these species, we evaluated their potential for biomass accumulation and regeneration following removal. We simulated the tree-climber relationship in a field experiment by varying light conditions and trellis availability, and by cutting aerial biomass. We also considered the spatial variability of the wetland's flood level. Ipomoea tiliacea accumulated more biomass at low flood levels, while Ipomoea indica accumulated more biomass at higher flood levels. Despite this, I. tiliacea accumulated more biomass over the entire flood level gradient and the highest flood levels seem to prevent regeneration in both species. There was no vine seed germination, so for both species, regeneration relied on shoot production. I. tiliacea increased its growth more than I. indica when trellises were available, even under shade. It means that that restoration conditions favor I. tiliacea, which makes its management specially challenging. We recommend characterizing hydrology of the site under restoration to design more effective Ipomoea control strategies. Future efforts to restore this forested freshwater wetland should select areas with the highest flood levels, where I. tiliacea growth is limited, ensuring that the trees to be planted can withstand the flood levels. Removal should be avoided during the dry season, when low flood levels favor regeneration in both species.

\section{Introduction}

The proliferation of exotic and native weed plants is one of the most visually obvious signs of ecosystem degradation (Bodmin, 2010). This phenomenon is becoming more frequent in wetlands, particularly as a result of the water table lowering and nutrient enrichment (Bodmin, 2010; Liu et al., 2016). Weed proliferation changes ecosystem structure and dynamics, and acts as a barrier to its restoration (Vargas Ríos, 2011).

The goal of wetland restoration is to reestablish important ecosystem services such as the regulation of the hydrological cycle, carbon storage and the production of goods that provide people with a livelihood and improve both their well-being and that of the local and regional economies, among other benefits (Howard et al., 2019; Ramsar Convention on Wetlands, 2018). While the importance of wetland restoration-and that of coastal wetlands in particular-has been globally acknowledged, the freshwater wetlands that are part of the coastal landscape have received much less attention from the scientific community, policy- and decision-makers (Vázquez-González et al., 2017).

In the last 100 years, freshwater forested wetlands on the central coast of Gulf of Mexico have been rapidly replaced by other types of land use; pastures for raising cattle in particular (Infante-Mata et al., 2014; Moreno-Casasola et al., 2010). Despite this ongoing threat, in Mexico there are no specific monitoring or protection programs, although these measures have been successfully implemented in mangroves, with positive effects including acquiring knowledge and conserving their structure and environmental services (Valderrama Landeros et al., 2015; Vázquez-González et al., 2017). 
Similarly, while sorely needed, restoration projects of freshwater forested wetlands in Mexico and the world are few and far between, and knowledge about applied restoration in this particular ecosystem is also limited. In Mexico, freshwater forest restoration projects began in 2010 in a degraded area of 0.5 $\mathrm{km}^{2}$ in the Ciénega del Fuerte Natural Protected Area (CFNPA). The area is covered by herbaceous vegetation, mainly grasses (Leersia hexandra and L. orizoides) and the herbaceous climbers Ipomoea indica and I. tiliacea, which sprawl over the grass or use trees or bushes as trellises (Sánchez Luna, 2018).

Controlling the proliferation of these two Ipomoea species has been one of the main challenges for restoration project because once the trees are planted, these vines climb over them, causing shade and mechanical damage that decreases tree growth and survival rates (Sánchez Luna, 2018). The vegetation layer formed by climbers has been removed at the beginning of the restoration process, but it regenerates and grows rapidly. This has forced periodic cutting to free the trees, requiring a significant investment of time and money (Sánchez Luna, 2018). The natural distribution area of these two species is extensive and includes the region of the CFNPA (Mcdonald, 1994). While they are not invasive species, due to their negative effect on restoration they are locally considered weeds (sensu Pyšek et al., 2004).

Woody and herbaceous climber proliferation is becoming frequent in both forest gaps and disturbed forests globally (Allen et al., 2007; Foster et al., 2008; Horvitz et al., 1998; Murphy et al., 2016; Schnitzer et al., 2000). At its worst, this phenomenon can lead to the replacement of forest vegetation by a dense layer of climbers that prevents ecological succession, even when active restoration efforts are being made, and this is happening in the CFNPA. Thus, during restoration climber removal is considered necessary to improve tree recruitment, growth and survival (César et al., 2016; Marshall et al., 2017; Myers et al., 1995).

Ipomoea is a broadly distributed tropical and subtropical genus that includes herbaceous climber species reported as invaders and weeds in wetlands. I. aquatica, I. carica and I. indica are listed as invasive plant species of the world as they grow forming tangles of intertwined stems in freshwater bodies in Florida and Cuba, in the disturbed coastal ecosystems of China and in the disturbed terrestrial and riverine ecosystems in South Africa, Australia and New Zealand (Weber, 2003). Some Ipomoea species are plagues in crops, such as I. heredifolia, I. grandifolia, I. nil, I. purpurea and I. quamoclit and are among the most harmful to sugar cane crops in Brazil (Kuva et al., 2007).

Ipomoea control is necessary to increase survivorship of planted trees during the restoration of the CFNPA's freshwater forested wetland. This control requires a better understanding of the potential biomass accumulation and regeneration of the vines following removal. These factors are modulated by the tree-climber relationship and wetland disturbance regime during restoration. With the initial removal of the vines and the planting of the trees, restoration activities introduce a disturbance because they change light and trellis availability. These climbers grow using the trees as trellises and, at the same time, shade and damage the trees. Additionally, in any wetland the hydroperiod should be considered the main factor that determines the disturbance regime and plant community composition (Keddy, 2010). In this study, we evaluated the regeneration capacity and biomass accumulation of I. tiliacea and I. indica under 
different conditions of trellis and light availability, and taking the wetland's flood level gradient into consideration.

We evaluated whether the increase in light availability that follows initial vegetation removal represents a window of opportunity for the regeneration and proliferation of these climbers, as light demanding plants (Davis et al., 2000; Leicht-Young et al., 2015; Putz, 1984; Royo et al., 2006; Sutherland, 2004; Young et al., 2010). We hypothesized that this window remains open until the understory becomes shaded, in this case, from treetop growth (Leicht-Young et al., 2015; Young et al., 2010). We also expected that tree planting would favor biomass accumulation in Ipomoea spp. as trees offer trellises for these climbers; the latter being a limiting resource for Ipomoea's growth, even though there are species that can live without trellises (den Dubbelden et al., 1995; Putz, 1984).

\section{Methodology}

\section{Study area:}

This study was done at the Ciénega del Fuerte Natural Protected Area (CFNPA), on the central coastal plain of the Gulf of Mexico in the state of Veracruz, Mexico. The climate in the region is wet and warm with three seasons: rainy from July to October, cold with northerly winds and rain from November to February and, dry from March to June (Infante Mata et al., 2012). Mean annual temperature is $24^{\circ} \mathrm{C}$ and total annual precipitation is around $1450 \mathrm{~mm}$ (Coordinación Estatal de Medio Ambiente, 2002; Infante Mata et al., 2012).

Wetlands are the main ecosystem on the CFNPA landscape, which has mangroves, and herbaceous and forested freshwater wetlands (Figure 1). Thalia geniculata and Typha domingensis are the most important species in the herbaceous wetlands (Sánchez-Higueredo et al., 2020), while Pachira aquatica is the dominant tree species in the forested freshwater wetlands (Infante Mata et al., 2012). The freshwater wetlands are flooded for about $40 \%$ of the year (Infante Mata et al., 2012), with the flood peak occurring in October when the water level rises to around $50 \mathrm{~cm}$ above ground level. During the following months the water level decreases steadily until May or June, when it drops to around $40 \mathrm{~cm}$ below ground level. Thereafter, the water level begins to rise and is above the soil's surface from September onward (Infante Mata et al., 2012).

For the study sites, areas covered by herbaceous vegetation dominated by Ipomoea spp. and Leersia spp. were chosen. These sites are similar to those where the restoration of flooded forest has been carried out, but in the study sites there has been no restoration, planting or control of herbaceous species.

\section{Experimental design:}

Twenty $10 \mathrm{~m} \times 10 \mathrm{~m}$ plots were randomly set up at the study site, with the criterion that they be separated by at least $20 \mathrm{~m}$. To isolate these plots from the surrounding vegetation, one-meter-wide corridors were created by periodically removing the vegetation cover around the plots. 
To assess the effect of the availability of support structures (trellises) on biomass accumulation by the vines, each plot was divided into two equal parts. Six PVC tubes, $15 \mathrm{~cm}$ in diameter and $150 \mathrm{~cm}$ in height, were installed on one side of the plot, separated from each other and from the edge of the quadrat by at least two meters. Texture was added to each tube by cutting vertical grooves along their length. Also, holes were drilled, into which we inserted four equidistant $0.5 \mathrm{~cm}$ diameter wood rods that protruded 10 $\mathrm{cm}$ out on each side, to simulate branches. On the other side of each plot, no supports were installed (Fig. 2 a-d).

To evaluate the effects of plant removal and shade, five of the plots described above were assigned to one of the following treatments: 1) Ipomoea removal at the beginning of the experiment. For this treatment all aerial biomass and part of the underground biomass were removed using the method developed by local workers and applied before trees are planted in the areas under restoration in CFNPA. The method consists of lifting and rolling up the thick herbaceous grass layer as is done with sod or turf (Fig. 2e); 2) Plots shaded with 65\% light attenuation mesh (Fig. 2c); 3) Ipomoea removal and plot shaded with $65 \%$ mesh; 4 ) Control treatment with no Ipomoea removal or plot shading.

To describe the hydrology of the study plots, a standpipe piezometer was placed in the southwest corner of each plot following the methodology proposed by Peralta Peláez et al. (2009). Water table fluctuation was monitored monthly and the maximum level recorded during the experiment (beginning of the wet season) was used to represent each plot.

To estimate Ipomoea regeneration, the regrowth and seedlings that appeared during the first month after removal were counted in two $1 \mathrm{~m}^{2}$ areas in the middle of the plot. To estimate Ipomoea biomass, growth was allowed during the dry season of 2017 (between April and August). After this period, each plot was subsampled by harvesting the total aerial biomass from six $1 \mathrm{~m}^{2}$ plots, three in the half plots with trellises and three in the half without trellises. Due to the challenge of transporting the enormous amount of harvested biomass out of the wetland to an oven, the fresh biomass was determined in situ for each species and, using previously calculated linear regression equations, the dry biomass of each species per square meter was estimated.

\section{Data Analyses}

The effects of flood level, initial plant removal, shade, trellis availability and their interactions on biomass accumulation by Ipomoea were tested using a generalized mixed model for each species (Zuur et al., 2011). The model included the experimental plot as a random variable. In each case, to fulfill the requirement for the homogeneity of variance, another term was included to model the variance. Additionally, to compare the biomass of the two species in plots without initial removal, without shade and without trellises, a t-test was done. All analyses were run using $R$ software, version 3.4.2 (R Core Team, 2020). For the mixed generalized models the $n / m e$ package was used (Pinheiro et al., 2018).

\section{Results}




\section{Effect of environmental variables associated with management on the biomass accumulation of Ipomoea tiliacea}

The accumulation of $I$. tiliacea biomass in plots where the herbaceous vegetation was removed at the beginning of the experiment was significantly lower than in plots without plant removal $\left(X^{2}=0.26, d . f .=1\right.$, $p<0.001$ ) (Table 1, Figure 3). Mean biomass of I. tiliacea at the end of the experiment in plots without plant removal was $143.9 \mathrm{~g} / \mathrm{m}^{2}$ and the maximum biomass recorded biomass for this species was 480.6 $\mathrm{g} / \mathrm{m}^{2}$. In contrast, in plots with initial removal of herbaceous vegetation the mean and maximum $\mathrm{l}$. tiliacea biomass values were $18 \mathrm{~g} / \mathrm{m}^{2}$ and $189.8 \mathrm{~g} / \mathrm{m}^{2}$, respectively. The latter values represent the biomass that this species regenerated over five months of growth during the dry season.

The interaction between shade, trellis availability and flood level also had a significant effect on the accumulation of $I$. tiliacea biomass $\left(X^{2}=2.39\right.$, d.f. $=1, p<0.01$; Table 1 , Figure 3$)$. When trellises were available, the biomass at the end of the experiment was always higher, in both shaded and unshaded plots. The increase in biomass was lower when the area was shaded, and was inversely proportional to the height of the flood level for the plot. Differences in the biomass accumulated by I. tiliacea resulting from shade and trellis availability are only evident when the flood level is relatively low, but in areas where the flood level is maximum, accumulated biomass tends to zero regardless of the availability of trellises and light.

\section{Effect of environmental variables associated with management on the biomass accumulation of Ipomoea indica}

The interaction between the initial removal of vegetation, shade and flood level had a significant effect on I. indica biomass accumulation $\left(X^{2}=8.56\right.$, d.f. $=1, p<0.01$; Table 1 , Figure 3$)$. When herbaceous vegetation was removed from the plot, I. indica accumulated less biomass. Additionally, in shaded plots, $I$. indica also accumulated significantly less biomass $\left(X^{2}=4.24\right.$, d.f. $=1, p<0.05$; Table 1$)$. So, in shaded plots, without plant removal, the mean biomass accumulated by I. indica was as low as it was in plots with initial herbaceous plant removal $\left(9.68 \mathrm{~g} / \mathrm{m}^{2}\right.$ in shaded plots vs. $44.0 \mathrm{~g} / \mathrm{m}^{2}$ in unshaded plots). Flood level had a significant effect on I. indica biomass accumulation too $\left(X^{2}=10.95\right.$, d.f. $=1, p<0.001$; Table 1$)$. In plots with a low flood level, accumulated biomass was low, while in plots with the maximum flood levels, the biomass accumulation was greater for this species, approaching values of $500 \mathrm{~g} / \mathrm{m}^{2}$. Even so, this effect of flood level was not evident in the shaded plots or those in which herbaceous vegetation was removed at the beginning (Figure 3 ).

The effect of trellis availability can only be understood by taking into account its interaction with the other three experimental variables $\left(X^{2}=4.945\right.$, d.f. $=1, p<0.005$; Table 1$)$. Trellis availability was associated with higher I. indica biomass accumulation only in plots with no initial plant removal, and the effect was higher in unshaded and plots with a high flood level. In contrast, the positive effect of trellis availability on I. indica biomass accumulation was not evident in areas with the lowest flood level (Figure 3). 
Table 1 The effects of initial removal of herbaceous vegetation (HR), shade (SH), supplementary trellises (ST) and flood level (FL) on biomass accumulation by two Ipomoea species in the CFNPA. Significant differences (p-value $\leq 0.05$ ) are in bold.

\begin{tabular}{|c|c|c|c|c|c|c|}
\hline & \multicolumn{3}{|c|}{ I. tiliacea } & \multicolumn{3}{|c|}{ I. indica } \\
\hline & $X^{2}$ & d.f. & $\mathrm{p}$-value & $X^{2}$ & d.f. & $\mathrm{p}$-value \\
\hline$\overline{\mathrm{HR}}$ & 0.05 & 1 & $<0.001$ & 2.59 & 1 & $\overline{0.11}$ \\
\hline $\mathrm{SH}$ & 0.12 & 1 & 0.82 & 4.24 & 1 & $<0.05$ \\
\hline ST & 0.02 & 1 & 0.87 & 0.82 & 1 & 0.36 \\
\hline FL & 0.33 & 1 & 0.56 & 10.98 & 1 & $<0.001$ \\
\hline IR : ST & 1.71 & 1 & 0.19 & 0.01 & 1 & 0.93 \\
\hline IR : FL & 0.05 & 1 & 0.83 & 0.004 & 1 & 0.95 \\
\hline $\mathrm{SH}: \mathrm{FL}$ & 4.88 & 1 & $<0.05$ & 0.69 & 1 & 0.40 \\
\hline SH: ST & 6.53 & 1 & $<0.05$ & 0.85 & 1 & 0.36 \\
\hline ST : FL & 6.32 & 1 & $<0.05$ & 2.12 & 1 & 0.14 \\
\hline SH : IR : ST & 2.77 & 1 & 0.10 & 3.02 & 1 & 0.08 \\
\hline $\mathrm{SH}: \mathrm{IR}: \mathrm{FL}$ & 0.69 & 1 & 0.40 & 8.57 & 1 & $<0.005$ \\
\hline $\mathrm{SH}: \mathrm{ST}: \mathrm{FL}$ & 7.54 & 1 & $<0.01$ & 0.04 & 1 & 0.83 \\
\hline IR : ST : FL & 1.00 & 1 & 0.32 & 0.20 & 1 & 0.65 \\
\hline SH : IR : ST : FL & 2.39 & 1 & 0.12 & 4.94 & 1 & $<0.05$ \\
\hline
\end{tabular}

\section{Comparison of the biomass accumulation patterns of Ipomoea tiliacea and Ipomoea indica}

Without herbaceous plant removal, trellises, or shade, Ipomoea biomass accumulation in this wetland can be explained by the interaction between species and flood level $(t=-2.183, p<0.05) . l$.

tiliacea accumulated an average of $81.61 \mathrm{~g} / \mathrm{m}^{2}$, and $l$. indica $33.4 \mathrm{~g} / \mathrm{m}^{2}(t=49.55, p<0.005)$. This difference was evident in plots with low and moderate flood levels, but disappeared in plots at high flood levels, because the increase in flood level was accompanied by an increase in I. indica biomass, while $I$. tiliacea's biomass remained constant across this flood gradient (Figure 3 ).

This pattern was also observed for both species in the absence of trellises, however, with trellises the final biomass of $I$. tiliacea increased, especially in areas with low flood levels, so there is an inverse relationship between flood level and the biomass accumulated by this species. This trend in I. tiliacea is the opposite of the direct relationship between the flood level and the biomass accumulated by I. indica. 
Likewise, the presence of trellises favored biomass accumulation in I. tiliacea, even in shaded plots and those with initial plant removal, while its positive effect on the biomass of $I$. indica was very low in shaded plots and practically null in plots with initial plant removal. In both cases, the greatest difference in biomass resulting from the presence of trellises occurred in the plots with no initial plant removal or shading, and was greater in magnitude for $I$. tiliacea. This species accumulated approximately four times more biomass (at the lower end of the flood gradient), while I. indica accumulated twice as much biomass (at the upper end of the flood gradient) in response to the availability of trellises (Figure 3).

In both species, biomass was negatively affected by the removal of herbaceous vegetation at the beginning of the experiment. Furthermore, for I. indica, the negative effect of shading was of the same magnitude as that of initial herb removal, while in I. tiliacea this effect was not as great. When the difference in accumulated biomass associated with the effect of shading was greatest (areas with trellises at the lower end of the flood gradient), the biomass of $I$. tiliacea in shaded areas was about two times less than that of unshaded areas. For $I$. indica, this maximum difference was more pronounced, with the final biomass about four times lower in shaded areas than in unshaded areas (in areas without initial plant removal at the upper end of the flood gradient) (Figure 3).

\section{Regeneration}

In both species, during the first month after plant removal regeneration only happened from shoot production by the rhizomes remaining in the soil and there was no seed germination. The number of sprouts was explained by the interaction between species, shade, and flood level $\left(X^{2}=5.116\right.$, d.f. $=1$, $p<0.05)$. On average, I. tiliacea produced 4.9 shoots $/ \mathrm{m}^{2}$, and $I$. indica produced 0.9 shoots $/ \mathrm{m}^{2}\left(X^{2}=16.29\right.$, d.f. $=1, p<0.001)$. This difference was greatest when the flood level was lowest and decreased as flood level increased, until it was virtually absent at the upper end of the flood gradient, where the number of sprouts produced by both species was around zero. While I. tiliacea produced fewer sprouts as the flood level increased, flood level did not affect sprout production in I. indica, a species that had slightly higher shoot production at the upper end of the flood gradient (Figure 4). This pattern was observed in both the plots with initial plant removal and in the shaded plots, while in the plots exposed to light, no effect of the flood level was observed. However, there were no plots at the lowest end of the flood gradient, so it was not possible to infer the effect of this variable on the production of Ipomoea shoots.

\section{Discussion}

In the CFNPA, the growth and regeneration patterns of I. indica and I. tiliacea in response to different flood levels and to the modification of light and trellis availability during the restoration process of the forested wetland, allow for a better understanding of the dynamics of the herbaceous vegetation and its interaction with the trees planted during restoration. This is the basis for proposing more effective management strategies that increase the probability of success in the restoration of this forested wetland. 
These two species of Ipomoea are affected and favored by different combinations of environmental conditions during restoration. I. tiliacea responds more efficiently to the modification of environmental conditions linked to restoration. This makes its management difficult and makes it the species that can cause the most damage to planted trees. To begin with, we confirmed the hypothesis that the absence of trellises limits the growth of Ipomoea in areas of herbaceous vegetation, since the biomass of both species was favored when this resource was available. However, this phenomenon is stronger in $I$. tiliacea, which suggests that this species has a better ability to locate and climb support structures. As a consequence, in an environment where trellises are available, I. tiliacea would be more successful than $I$. indica (den Dubbelden et al., 1995) and, with its capacity to develop a large amount of biomass, is the most problematic of these two species in the context of restoration. This pattern is consistent with observations made in lianas, for which growth speed in response to the availability of support marks the difference between invasive and non-invasive species (Leicht-Young et al., 2015).

The favorable effect of trellis availability on the final biomass of $I$. tiliacea, even under shaded conditions, does not support the hypothesis that these vines have a high demand for light. However, it does support the idea that the growth of these climbing plants is limited by the availability of trellises rather than by the availability of light as Putz (1984) suggested. In contrast, the low biomass accumulation of $I$. indica under shaded conditions, despite the availability of the trellises, does not concur with Putz's idea, but fits the shade intolerance hypothesis for this vine. Thus, in general, the results of our study suggest that the shade tolerance of herbaceous climbers such as Ipomoea spans a broader range than is assumed characteristic of them as pioneer plants (Schnitzer and Bongers 2002; Toledo-Aceves and Swaine 2008). Furthermore, the response of climbing plants to different degrees of light availability helps us understand their diversity and distribution in ecosystems (Schnitzer et al. 2004).

The shade tolerance of $I$. tiliacea supports the idea that some species of climbers combine the characteristics of both light-demanding and shade-tolerant plants. While they require lots of light to establish, once established they can persist even under the shade of a tree canopy (Schnitzer and Bongers 2002). This makes their management even more difficult during the restoration of the forested wetland, since they will not disappear or notably decrease in abundance when the canopies of the trees planted increase and create more shade.

However, the shade tolerance of I. tiliacea was lower in plots with higher flood levels, the opposite pattern to that of $I$. indica, the species that had a higher tolerance to flooding, at least when not stressed by shade. Thus, the growth patterns of these two species would seem to indicate a compromise between shade tolerance and flood tolerance (Hall and Harcombe 1998). As suggested by some authors (Hall and Harcombe 1998; Battaglia and Sharitz 2006), contrast in the response of species to these two environmental variables helps us better understand the distribution patterns of plants in wetlands.

In the areas with plant removal, the accumulation of biomass observed along the flood gradient and with light availability is related not only to the effect that these variables have on the growth of established plants, but also to their effect on the regeneration capacity of the two species, after being cleared. In 
areas with plant removal, I. tiliacea had the same biomass accumulation patterns that it had in areas where herbaceous layer was left untouched. In contrast, the tendency of $I$. indica to accumulate higher biomass in areas with high levels of flooding and in response to the availability of trellises, was not observed in areas with plant removal. This suggests that this species can be controlled relatively easily during restoration efforts, as its shade tolerance is low and it has a low regeneration capacity after the herbaceous layer is removed, at least in the short term.

Since it has been observed that high light availability favors the regeneration of climbing plants and weeds in general (Horvitz et al. 1998; Ledo and Schnitzer 2014), we expected plant removal to have a lower impact in plots completely exposed to light than in those that were shaded. However, the results show the opposite pattern, since the biomass of both species was lower in plots with plant removal exposed to light than in those that were shaded. It is necessary to keep in mind that in this combination of treatments sampling only covered areas with high levels of flooding. Since this zone of the gradient is the least favorable for I. tiliacea, this species is expected to accumulate more biomass after plant removal in areas with lower flood levels. In contrast, high flood values are the most favorable for I. indica in plots with the herbaceous vegetation intact. Therefore, the low biomass of Ipomoea in these plots is not explained by the effect of flood level on the growth of established plants, but rather by the effect it has on its regeneration.

From the start of plant removal, the level of the water table in areas with no to very low Ipomoea regeneration was very close to the ground's surface or even above it, thus the remaining underground biomass was always under flooded conditions. This would have limited the mechanisms of flood tolerance and restricted the possibility of sprouting from the rhizome. This pattern denotes an interaction between defoliation stress and flood stress that has been previously observed in some wetland grasses for which regeneration after herbivory is much lower when they are in flooded conditions (Striker et al., 2008).

Likewise, even when sprouting occurs, the survival of plants that are not very tolerant to flooding is severely limited during the early stages of growth (Kim et al., 2013). The probability of sprout (o shoot) survival decreases when the flood level increases, since the height that the plant must reach before emerging is greater (Edwards et al., 2003). The probability of survival also decreases when the sprouts are submerged during their early development and have a lower carbohydrate reserve (Mauchamp et al., 2001). Taken together, this indicates that shoot production and survival will be lower in topographically less elevated areas, where both the duration and the level of the flood are greater.

The regeneration of Ipomoea from shoot recruitment but not from the germination of seeds concurs with the findings of various studies that indicate vegetative reproduction is the most important mechanism in the colonization and proliferation of climbing plants, especially in areas with a high degree of disturbance and in response to disturbance events (Young and Peffer 2010; Ledo and Schnitzer 2014). In this sense, although the results of this study suggest that when the remaining rhizome is in waterlogged soil, the vegetative reproduction of Ipomoea after plant removal is restricted, it is known that this type of rhizome 
can survive long periods in flooded soils (Capon, 2016). Therefore, this effect could be limited to the wet season and shoot production could be reactivated in the dry season.

Finally, the observed effects of flooding and shading on shoot production shows that it follows the same patterns as the accumulation of biomass in the two species, thus reinforcing the importance of vegetative reproduction in the life history of both $I$. indica and $I$. tiliacea. It is worth mentioning that, since shoots were counted only once (one month after planting), it is likely that the number of shoots recorded reflects the speed with which each species can produce them-higher in I. tiliacea in this case-and not necessarily the species' ability to produce shoots in the long term.

The positive effect of trellis availability on biomass accumulation is more evident in the absence of shade, and particularly in I. tiliacea (the more abundant and problematic of the two species). It illustrates what occurs when trees with thin trunks and small crowns are planted: vine growth is facilitated and the growth and survival of trees is negatively impacted. Thus, removal of the initial herbaceous layer is necessary at the start of the restoration process in order to limit the impact of climbers on the recently planted trees.

The regeneration and growth patterns of the vines in this wetland also show that an understanding of hydrology is very important when designing control strategies for the vines of the genus Ipomoea during floodplain forest restoration in the CFNPA. This highlights the importance of characterizing the topography, as well as the spatial and temporal variations in hydrology in wetland restoration projects.

Increasing the level and duration of flooding has been proposed as a strategy to control weed growth in wetlands, when the desired vegetation has greater tolerance to flooding (Laubhan et al., 2006; Liu et al., 2016; López-Rosas et al., 2013). However, we argue that for the CFNPA this is neither feasible nor necessary. Instead, we propose taking advantage of the heterogeneity of the microtopography. In this study we found that the flood level gradient spans about $40 \mathrm{~cm}$ at the beginning of the wet season.

Therefore, we suggest prioritizing areas with higher flood levels for planting trees, where the proliferation of the most problematic species is not favored and the production of regrowth of both species of Ipomoea is limited, at least in the short term. Trees tolerant to these flood levels should be chosen. Likewise, the removal of the vines would preferably be carried out during the weeks before the water level increases above the soil's surface, from July to August, to ensure that the vines' underground biomass remains in flooded soils that limit vegetative regeneration for as long as possible. In contrast, cutting and plant removal should be avoided when the dry season begins, since the low level of the water table during this season will favor the growth of I. tiliacea, and the regeneration of both I. tiliacea and I. indica.

\section{Declarations}

Acknowledgements 
We are grateful to the Sociedad Cooperativa de Producción Pesquera Río Soteros, and especially to Guillermo Marín, Reyna Martínez and Guadalupe Martínez for their help during the field work. We thank Francisco Mora of the Support in Statistics, Modelling and Data Management Unit of IIES (UNAM) for his advice on the statistical analyses, and Roberto Monroy for his help with the maps. We thank Bianca Delfosse for revising the English.

Funding: This study was funded by Mexico's National Science and Technology Council (CONACYT, Scholarship No. 606591 awarded to L Aguirre Franco) and the National Forestry Commission (CONAFOR, Project No. 2015302N0036).

Conflict of interest: The authors declares no conflicts of interest or competing interests.

Data availability: Available upon request.

Code availability: Not applicable.

\section{References}

Allen BP, Sharitz RR, Goebel PC (2007) Are lianas increasing in importance in temperate floodplain forests in the southeastern United States? Forest Ecology and Management, 242(1), 17-23. doi:

10.1016/j.foreco.2007.01.027

Bodmin K (2010). Weeds. In Peters M, Clarkson B (Eds.), Wetland restoration: a handbook for New Zealand freshwater systems. (pp. 44-45). Lincoln: . Manaaki Whenua Press.

César RG, Holl KD, Girão VJ, Mello FN, Vidal E, Alves MC, Brancalion PH (2016) Evaluating climber cutting as a strategy to restore degraded tropical forests. Biological Conservation, 201, 309-313. doi:

10.1016/j.biocon.2016.07.031

Coordinación Estatal de Medio Ambiente (2002). Área Natural Protegida Ciénega del Fuerte. Programa de Manejo.

Davis MA, Thompson K (2000) Eight ways to be a colonizer, two ways to be an Invader: A proposed nomenclature scheme for invasion ecology. Bulletin of the Ecological Society of America, 81(3), 226-230. doi: $10.2307 / 20168448$

den Dubbelden KC, Oosterbeek B (1995) The availability of external support affects allocation patterns and morphology of herbaceous climbing plants. Functional Ecology, 9(4), 628-634.

doi:10.2307/2390154

Foster JR, Townsend PA, Zganjar CE (2008) Spatial and temporal patterns of gap dominance by lowcanopy lianas detected using EO-1 Hyperion and Landsat Thematic Mapper. Remote Sensing 0 Environment, 112, 2104-2117. doi: 10.1016/j.rse.2007.07.027 
Horvitz CC, Pascarella JB, McMann S, Freedman A, Hofstetter RH (1998) Functional roles of invasive nonindigenous plants in Hurricane-affected subtropical hardwood forests. Ecological Applications, 8(4), 947-974. doi: 10.1890/1051-0761(1998)008[0947:FROINI]2.0.CO;2

Howard J, Hoyt S, Isensee K, Pidgeon E, Telszewski M (2019) Coastal Blue Carbon: methods for assessing carbon stocks and emissions factors in mangroves, tidal salt marshes, and seagrass meadows. Conservation International, Intergovernmental Oceanographic Commission of UNESCO, International Union for Conservation of Nature,.

Infante-Mata D, Moreno-Casasola, P, Madero-Vega C (2014) ¿Pachira aquatica, un indicador del límite del manglar? Revista Mexicana de Biodiversidad. doi: 10.7550/rmb.32656

Infante Mata D, Moreno-Casasola P, Madero-Vega C (2012) Litterfall of tropical forested wetlands of Veracruz in the coastal floodplains of the Gulf of Mexico. Aquatic Botany, 98(1), 1-11. doi:

10.1016/j.aquabot.2011.11.006

Keddy PA (2010) Wetland ecology: Principles and conservation (Second ed). Cambridge University Press.

Kuva MA, Pitelli RA, Salgado TP, Alves PLCA. (2007). Fitossociologia de comunidades de plantas daninhas em agroecossistema cana-crua. Planta Daninha, 25(3), 501-511. doi: 10.1590/S010083582007000300009

Laubhan M, Shaffer T (2006) Seed germination of Cirsium arvense and Lepidium latifolium: Implications for management of montane wetlands. Wetlands, 26(1), 69-78. doi: 10.1672/0277-

5212(2006)26[69:SGOCAA]2.0.C0;2

Leicht-Young S, Pavlovic N (2015) Lianas as invasive species in North America. In: A. Schnitzer SA, Bongers F, Burnham RJ, Putz FE (Eds.) Ecology of lianas (pp. 429-442). Willey Blackwell.

doi:10.1002/9781118392409.ch28

Liu B, Jiang M, Tong S, Zhang W, Wu H, Liu Y, Lu X (2016) Differential flooding impacts on Echinochloa caudata and Scirpus planiculmis: Implications for weed control in wetlands. Wetlands, 36(5), 979-984. doi: 10.1007/s13157-016-0805-0

López-Rosas H, Moreno-Casasola P, López-Barrera F, Sánchez-Higueredo L, Espejel González V E, Vázquez Benavides J (2013) Interdune wetland restoration in Central Veracruz, Mexico: Plant diversity recovery mediated by the hydroperiod. In Martínez ML, Gallego-Fernández JB, Hesp PA (Eds.) Restoration of coastal dunes (pp. 255-269). doi: 10.1007/978-3-642-33445-0

Marshall AR, Coates MA, Kivambe E, Mnendendo H, Mtoka S, Mwakisoma R, Lemos de Figueredo R, Njilima FM (2017) Liana cutting for restoring tropical forests: A rare paleotropical trial. African Journal of Ecology. doi: 10.1111/aje.12349. 
Mcdonald A (1994) Convolvulaceae II. In Flora de Veracruz: Vol. Fascículo. Xalapa, Veracruz, México: Instituto de Ecología A.C. - University of California, Riverside, CA.

Moreno-Casasola P, Infante-Mata D (2010) Veracruz. Tierra de ciénagas y pantanos. Verecruz: Gobirno del Estado - Universidad Veracruzana - Instituto de Ecología A.C.

Murphy HT, Metcalfe DJ, Forest T, Murphy H (2016) The perfect storm: Weed invasion and intense storms in tropical forests. Austral Ecology, 41, 864-874. doi: 10.1111/aec.12376

Myers RS, Shaffer GP, Llewellyn DW (1995) Baldcypress (Taxodium distichum (L.) Rich.) restoration in southeast Louisiana: The relative effects of herbivory, flooding, competition, and macronutrients. Wetlands, 15(2), 141-148. doi: 10.1007/BF03160667

Peralta-Peláez, LA, Moreno-Casasola P, Infante-Mata D (2009) Construcción e instalación de piezómetros. In Moreno-Casasola P, Warner B (Eds.) Breviario para describir, observar y manejar humedales.

Pinheiro J, Bates D, DebRoy S, Sarkar D (2018) R Core Team. Linear and Nonlinear Mixed Effects Models. $R$ Package Version 3.1.137. Retrieved from https://cran.r-project.org/package=nlme.

Putz FE (1984) The natural historry of lianas in Barro Colorado Island, Panamá. Ecology, 65(6), 17131724. doi: $10.2307 / 1937767$.

Pyšek P, Richardson DM, Rejmánek M, Webster GL, Williamson M, Kirschner J (2004). Alien plants in checklists and floras: towards better communication between taxonomists and ecologists. Taxon, 53(February), 131-143. doi: 10.2307/4135498.

R Core Team. (2020). R: A Language and Environment for Statistical Computing. Vienna, Austria: $\mathrm{R}$ Foundation for Statistical Computing. Retrieved from https://www.r-project.org/

Ramsar Convention on Wetlands (2018) Global Wetland Outlook: State of the World's Wetlands and their Sevives to Peoople 2018. Galnd, Swizerland: Ramsar Convention Secretariat. Retrieved from https://www.global-wetland-outlook.ramsar.org/outlook

Royo AA, Carson WP (2006) On the formation of dense understory layers in forests worldwide: consequences and implications for forest dynamics, biodiversity, and succession. Canadian Journal of Forest Research, 36(6), 1345-1362. doi: 10.1139/x06-025

Sánchez-Higueredo LE, Ramos-Leal JA, Morán-Ramírez J, Moreno-Casasola P, Rodríguez-Robles U, Hernández Alarcón ME (2020) Ecohydrogeochemical functioning of coastal freshwater herbaceous wetlands in the Protected Natural Area, Ciénaga del Fuerte (American tropics): Spatiotemporal behaviour. Ecohydrology, 13(2), 1-13. doi: 10.1002/eco.2173

Sánchez Luna OI (2018). Evaluación de los cambios en la estructura y funcionamiento de la selva inundable del Área Natural Protegida Ciénega del Fuerte, Tecolutla, Veracruz, durante las acciones de 
restauración. Instituto de Ecología.

Schnitzer SA, Dalling JW, Carson WP (2000) The impact of lianas on tree regeneration in tropical forest canopy gaps: Evidence for an alternative pathway of gap-phase regeneration. Journal of Ecology, 88(4), 655-666. doi: 10.1046/j.1365-2745.2000.00489.x

Sutherland S (2004). What makes a weed a weed: life history traits of native and exotic plants in the USA. Oecologia, 141(1), 24-39. doi: 10.1007/s00442-004-1628-x

Valderrama-Landeros H, Rodríguez-Zúñiga, MT, Troche-Souza C, Velázquez-Salazar S, Villeda-Chávez E, Alcántara-Maya J-A, Vázquez-Balderas B, Cruz-López MI, Ressl R (2015) Manglares de México. Actualización y exploración de los datos del sistema de monitoreo 1970/1980-2015. Ciudad de México: Comisión Nacional para el Conocimiento y Uso de la Biodiversidad.

Vargas Ríos O. (2011). Restauración ecológica: Biodiversidad y conservación. In Acta biol. Colomb (Vol. 16, Issue 2).

Vázquez-González C, Moreno-Casasola P., Hernández ME, Campos A, Espejel I, Fermán-Almada, JL (2017) Mangrove and freshwater wetland conservation through Carbon offsets: A cost-benefit analysis for establishing environmental policies. Environmental Management, 59(2), 274-290. doi: 10.1007/s00267016-0790-3

Weber E (2003) Invasive plant species of the world: A reference guide to environmental weeds. Wallingford, UK; Cambridge, Massachusetts: CABI Publishing.

Young TP, Peffer E (2010) "Recalcitrant understory layers" revisited: arrested succession and the long lifespans of clonal mid-successional species. Canadian Journal of Forest Research, 40, 1184-1188. doi: 10.1139/X10-066

Zuur AF, Leno EN, Walker NJ, Saveliev AA, Smith GM (2011). Mixed effects models and extensions in ecology with R. In Gail M, Krickeberg, K, Samet JM, Tsiatis A, Wong W (Eds.), Statistics for biology and health (Vol. 36). Springer. doi: 10.1016/B978-0-12-387667-6.00013-0

\section{Figures}



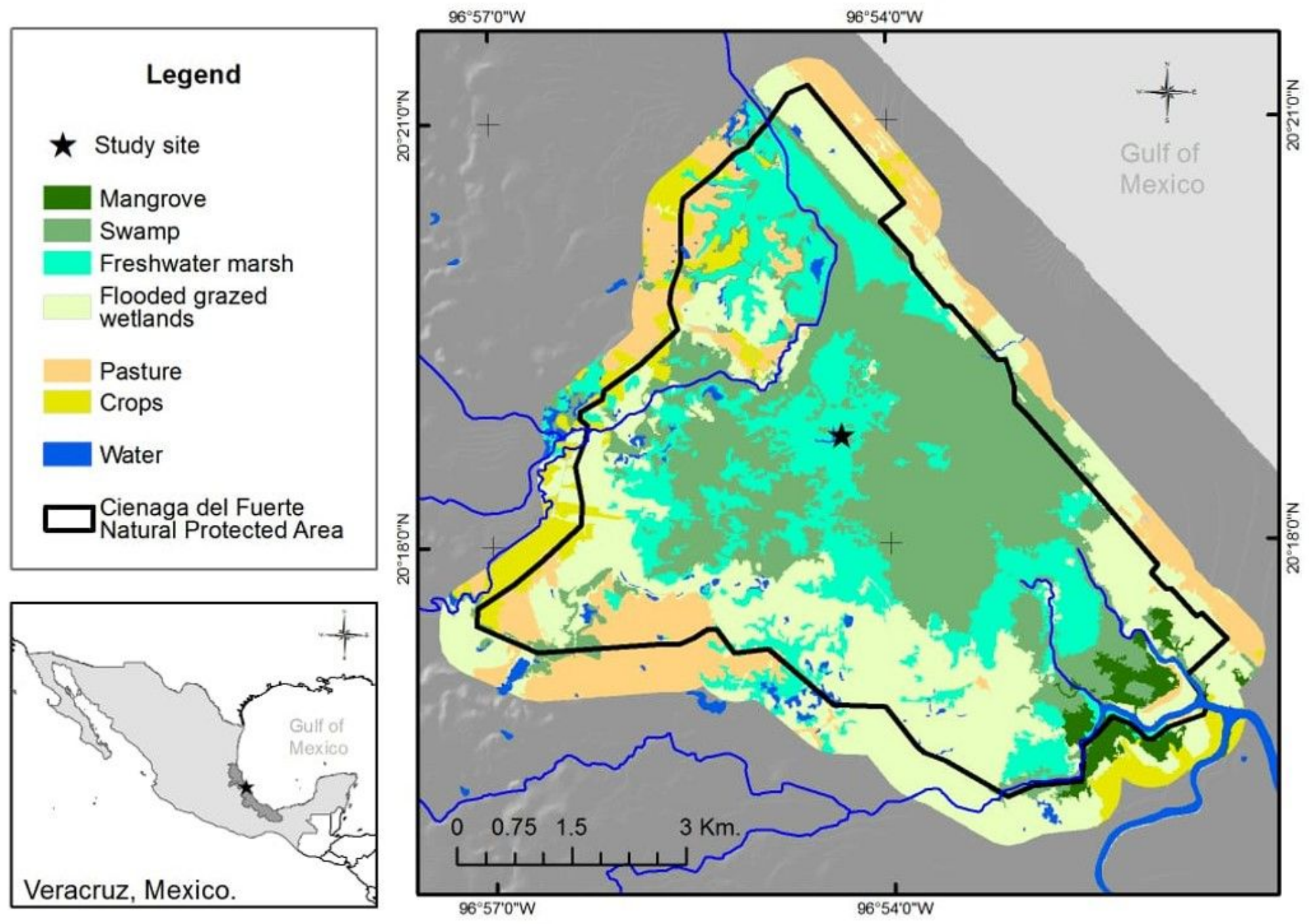

Figure 1

Location of the Ciénega del Fuerte Natural Protected Area on the coastal plain of the Gulf of Mexico. The vegetation and types of land use in the CFNPA and the study site (star) are shown. 

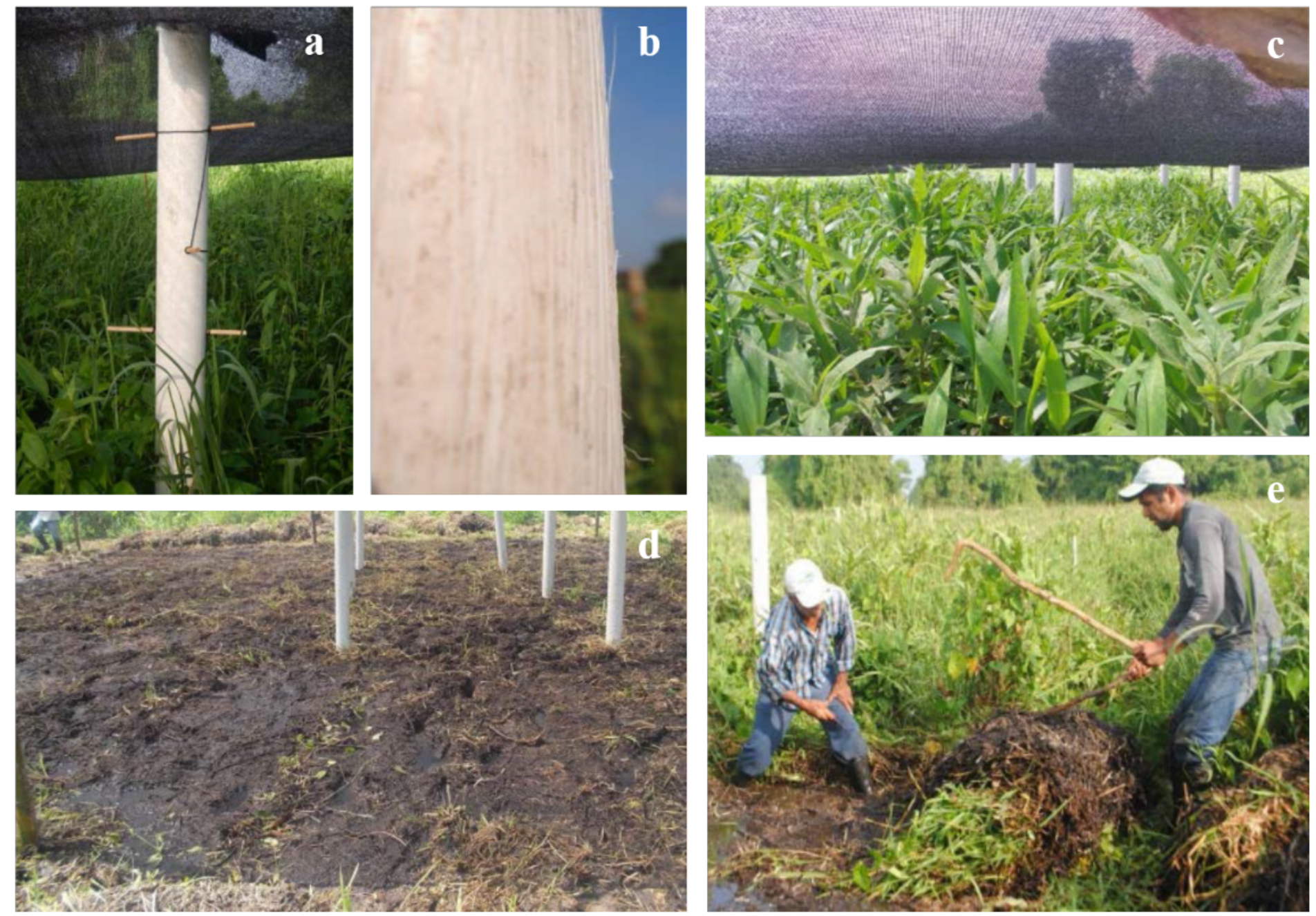

\section{Figure 2}

Photographs of the installation of the experiment. a. PVC trellises with wood rods simulating branches; $b$. Detail of the texture on the trellises; c. Trellis setup in an experimental plot without Ipomoea removal and with shade; $d$. Trellis setup in an experimental plot with Ipomoea and herbaceous plant removal and without shade; e. Herbaceous vegetation removal method using a staff and a machete. 


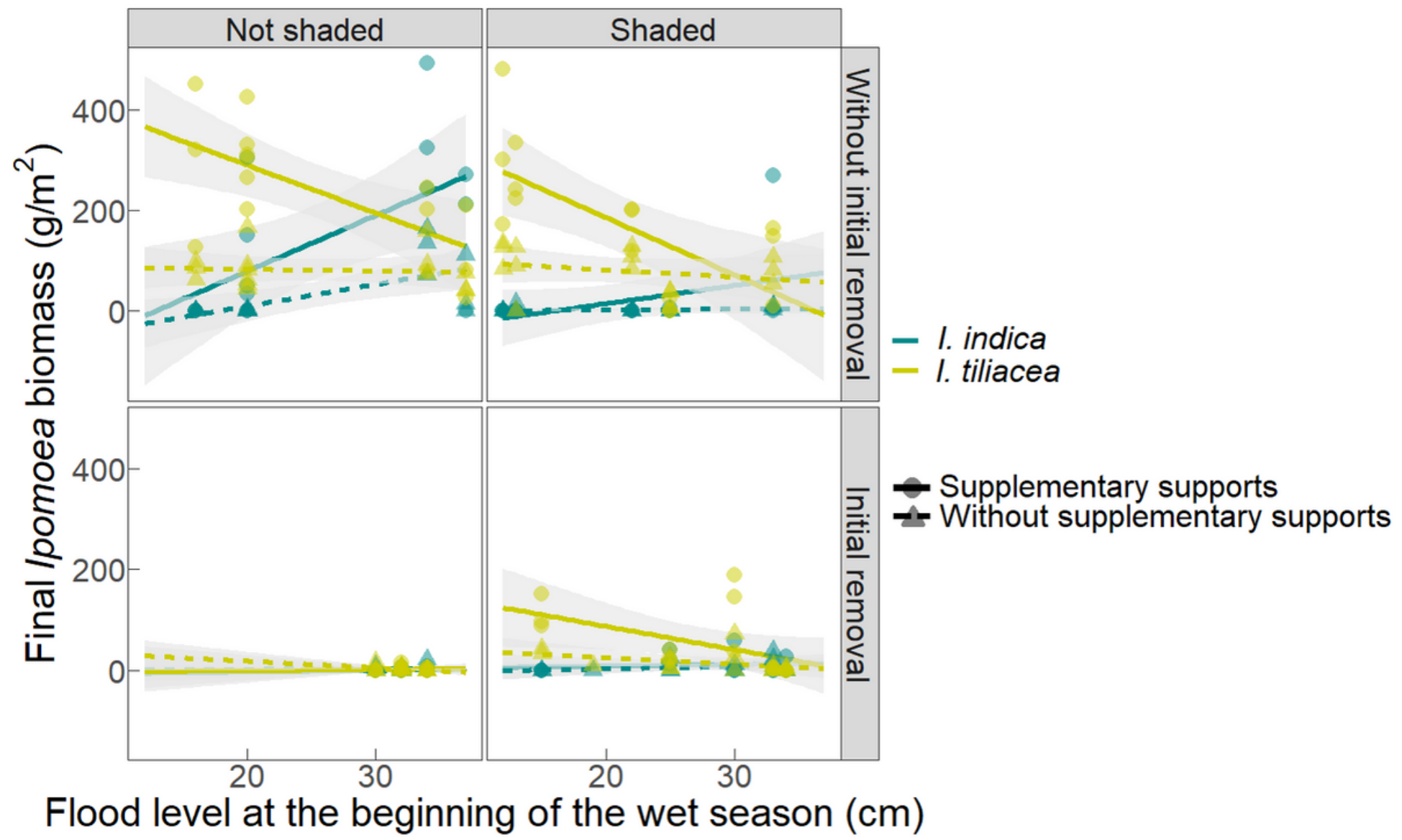

Figure 3

Biomass accumulation in Ipomoea indica and Ipomoea tiliacea under contrasting conditions of trellis availability, shade and initial herbaceous vegetation removal, along a flood level gradient in the CFNPA wetland.

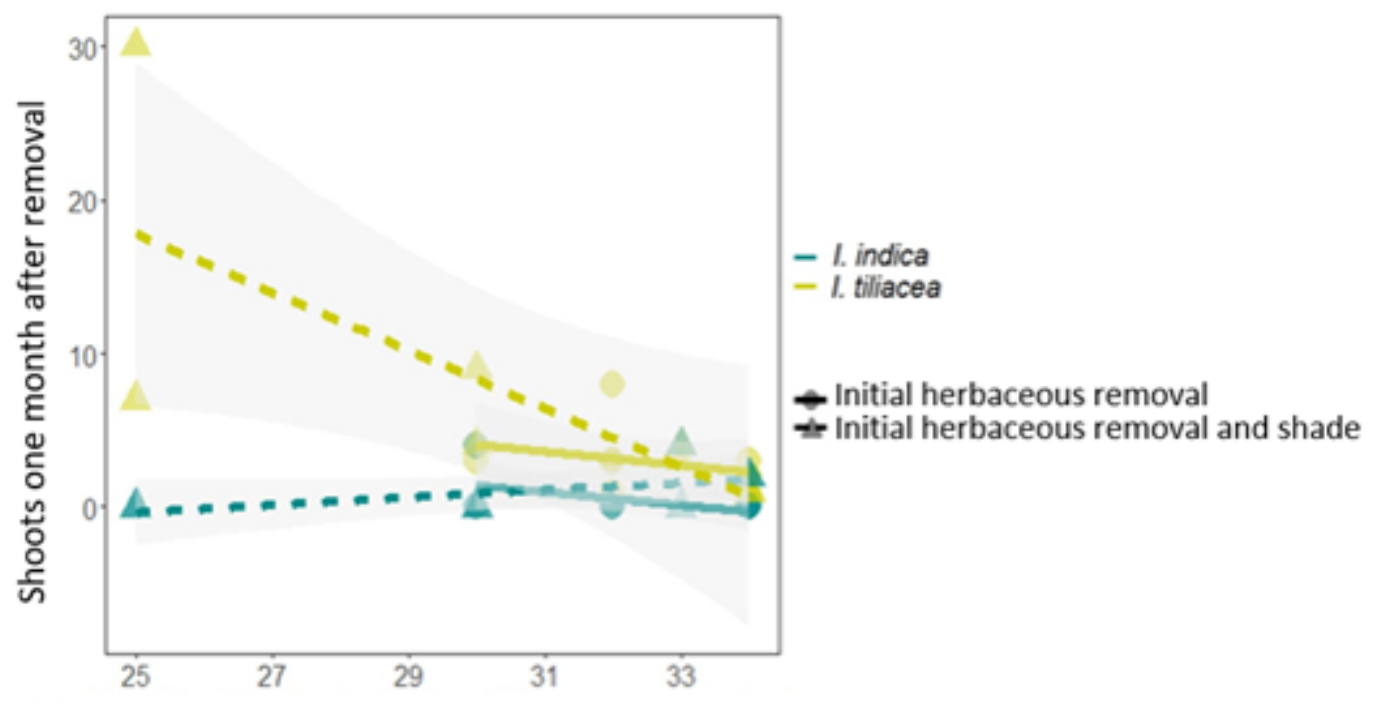

Flood level at the beginning of the wet season $(\mathrm{cm})$ 


\section{Figure 4}

Number of shoots produced by Ipomoea indica and Ipomoea tiliacea during the month after initial removal of the herbaceous vegetation. 